\title{
Evolving Insurgency and India's Counter-Insurgency Options: Entering into the Age of Fourth-Generation Warfare?
}

\section{Shantanu Chakrabarti *}

The end of the Cold War was celebrated in many circles as marking an end to a pattern of global relations that was determined largely by conflict, a shift that was thought to augur an era of greater cooperation and peace. However, these hopes were soon seen to be mistaken. While the number of inter-state conflicts has certainly come down in the post-Cold War years, externally induced factors, as well as the rising incidence of collapsing internal institutions, helped spur the rise of intra-state conflicts of various types. One is perhaps forced to acknowledge at least the partial validity of John Mearsheimer's 1990 prophecy that the world would soon miss the order of the Cold War era as we leap into "untamed anarchy." In cases of such internal conflicts, the most alarming fact has been the increasing incidence of states' failure to ensure the supply of public goods to their citizens - most critically the failure to ensure security. As one analyst argues:

There is a hierarchy of political goods. None is as critical as the supply of security, especially human security. Individuals alone, almost exclusively in special or particular circumstances, can attempt to secure themselves. Or groups of individuals can band together to organize and purchase goods or services that maximise their sense of security. Traditionally, and usually, however, individuals and groups cannot easily or effectively substitute private security for the full spectrum of public security. The state's prime function is to provide that political good of security: to prevent cross-border invasions, and infiltrations, and any loss of territory; to eliminate domestic threats to or attacks upon the national order and social structure; to prevent crime and any related dangers to domestic human security; and to enable citizens to resolve their disputes with the state and with their fellow inhabitants without recourse to arms or other forms of physical coercion. ${ }^{2}$

One major cause behind the failure of the state to either ensure public security or reduce intra-state level conflicts has been its inability to tackle the evolving and wideranging threats related to insurgency. Insurgency-related threats have undoubtedly become the biggest security threat to the nation-state system in current times, far outweighing the diminishing risk of inter-state conflict.

\footnotetext{
Shantanu Chakrabarti is a Reader in the Department of History and the Academic Convenor in the Institute of Foreign Policy Studies at the University of Calcutta.

1 John J. Mearsheimer, "Why We Will Soon Miss the Cold War," The Atlantic Monthly (August 1990): 35 .

2 Robert I. Rotberg, "Failed States, Collapsed States, Weak States: Causes and Indicators," in State Failures and State Weakness in a Time of Terror, ed. Robert I. Rotberg (Washington, D.C.: The World Peace Foundation \& Brookings Institution Press, 2003), 3.
} 


\section{The Rising Threat of Insurgency in the Post-Cold War World}

Intra-state conflicts directed against the state can be of various nature and origin. The idea that different cultures produce different concepts and ideologies of conflict is not altogether new. Such ideas, for instance, have long been a subject of critical inquiry within the broader fields of military and strategic culture. While discussing the outcome of the First Gulf War, the prominent military historian John Keegan, for instance, referred to the "inutility of the 'Western way of warfare' when confronted by an opponent who refuses to share its cultural assumptions." ${ }^{3}$ A broader theoretical explanation of the insurgencies that have emerged in the post-Cold War years, however, has been provided by the concept of "Fourth Generation Warfare" (4GW). The concept was first circulated in 1989, when five U.S. military officers published an article titled "The Changing Face of War: Into the Fourth Generation" in the Marine Corps Gazette. ${ }^{4}$ But the concept was further explored and studied in a more elaborate manner by another U.S. Marine Corps officer, Thomas X. Hammes. According to Hammes, human history has witnessed the evolution of warfare through four generations. The first-generation war, which reached its culmination with the end of the Napoleonic Wars, transformed the nature of ancient and medieval warfare into one that involved larger armies and massed direct-fire weapons. The second generation of warfare, which evolved since the end of the Napoleonic Wars and peaked during the First World War, involved massed firepower along with the use of developed transport and communication networks. Third-generation warfare reached its apogee point during the Second World War, with the transformation of the essentially defensive nature of second-generation warfare into a war of maneuver. The present-day form of asymmetric warfare, according to Hammes, represents fourth-generation warfare, which has evolved in the period since the end of World War II, and was largely influenced by Mao's model of peasant insurrection. Hammes writes:

Fourth-generation warfare (4GW) uses all available networks - political, economic, social, and military - to convince the enemy's political decision makers that their strategic goals are either unachievable or too costly for the perceived benefit. It is an evolved form of insurgency. Still rooted in the fundamental precept that superior political will, when properly employed, can defeat greater economic and military power, 4GW makes use of society's networks to carry on its fight. Unlike previous generations of warfare, it does not attempt to win by defeating the enemy's military forces. Instead, via the networks, it directly attacks the minds of enemy decision makers to destroy the enemy's political will. Fourth-generation wars are lengthy measured in decades rather than months or years. ${ }^{5}$

3 John Keegan, A History of Warfare (London: Pimlico, 1994), xi.

4 For details, see William S. Lind, Keith Nightengale, John F. Schmitt, Joseph W. Sutton, and Gary I. Wilson, "The Changing Face of War: Into the Fourth Generation," Marine Corps Gazette (October 1989): 22-26.

5 Thomas X. Hammes, The Sling and the Stone: On War in the $21^{\text {st }}$ Century (New Delhi: Zenith Press \& Manas Publishers, 2006), 2. 
Hammes' generational paradigm, however, has been questioned by several critics, leading to a larger debate over the entire concept of fourth-generation warfare. According to one of his critics, for instance, what we have witnessed over the past fifteen years is the bifurcation of the contemporary international security system. That is, a split has occurred between a traditional twentieth-century state-centered paradigm and a new set of sub-state and trans-state strata, resulting in the rise of a new spectrum of warfare that reflects the merging of complex and overlapping modes of armed conflict. $^{6}$

The task confronting military theorists, therefore, as Evans argues, is "not to seek artificial categorization based on alleged generations, or waves of activity, but to undertake an intellectual exploration of the growing interaction between inter-state, substate and trans-state conflict. The need is for analysts to conduct a rigorous investigation of the phenomenon of merging war forms - internal, international, post-modern, modern and pre-modern.,"

In spite of its flaws, however, the $4 \mathrm{GW}$ model does manage to provide observers with some useful analytical tools to help decipher the nature of modern insurgencies. As one analyst notes, for modern insurgents, $4 \mathrm{GW}$ is in many ways a response to the increased reliance on technology that is seen in the armies of wealthier states. Taking its inspiration from the Maoist idea of "people's war," which held that war could be successfully waged by low-tech insurgents against better-equipped formal militaries, this form of warfare has become a defining feature of the 1990s and the early part of the twenty-first century. ${ }^{8}$ As another scholar has written,

It could hardly be argued that insurgent-type conflict was new but it now seemed that conflicts between states and a new kind of 'glocal' insurgent (that is, those operating in local and global realms simultaneously) - empowered in some places by the new technologies and openness of late twentieth-century globalization-would be the dominant idiom of warfare for the foreseeable future. Certainly, the way that contemporary globalization had set up a global communications network, increased the flows of goods and peoples around the world, and made weapons and other materials more available, enabled some small non-state groups to project themselves across the world. The outbreak of the 'global war on terrorism' from 11 September 2001 would provide the ultimate example of a fourth-generation enemy and battlefield. ${ }^{9}$

6 Michael Evans, "Elegant Irrelevance Revisited: A Critique of Fourth-Generation Warfare," Contemporary Security Policy 26:2 (2005): 245.

7 Ibid., 247.

8 Paul Jackson, “Is Africa Seeing Fourth Generation Warfare, Or is the Model Flawed?" Small Wars and Insurgencies 18:2 (June 2007): 147.

9 Simon Murden, "Staying the Course in Fourth-Generation Warfare," in Dimensions of Counter-Insurgency: Applying Experience to Practice, eds. Tim Benbow and Rod Thornton (New York: Routledge, 2008), 192. 
This new form of warfare, it has been argued, pits nations against non-state organizations and networks that include not only terrorists or extremists but also ethnic groups, organized criminal networks, and drug traffickers. Its evolutionary roots may lie in guerrilla warfare, the Leninist theory of insurrection, and old-fashioned terrorism, but it is rendered more pervasive and effective by the technologies, mobility, and miniaturized instrumentalities spawned by the age of computers and mass communication. $^{10}$

Whether or not one accepts the characterization of modern insurgencies as conforming to the $4 \mathrm{GW}$ model, one must admit the evolving and highly diffused and diversified nature of such insurgencies. Faced with this new threat to their existence, nation-states have also tried to evolve new counter-insurgency measures. The next section of this essay will highlight some of these new trends.

\section{Defeating Insurgency: New Trends in Counter-Insurgency Theory}

Counter-insurgency, commonly abbreviated as COIN, is a type of military campaign used in a situation of insurrection, rebellion, or civil war, and is usually conducted in conjunction with conventional military operations, propaganda, and psychological operations. While such operations do not represent a dramatically new development in military history, recent global developments have led to the evolution of such patterns of conflict into highly sophisticated types of campaigns. In the post-2001 period, to be more specific, counter-insurgency operations have become increasingly difficult given the emergence of a new set of paradigms for insurgency. If non-linear, diffused, and extensively prolonged forms of warfare even roughly based on the 4GW model are becoming the adopted model of insurgents of varied types, is it possible for democratic, pluralist states to adopt effective counter-insurgency measures? Many analysts conclude rather pessimistically that democracies by their very nature fail to adopt effective counter-insurgency measures in asymmetric war situations. According to Gil Merom, for instance, what essentially prevents modern democracies from winning small wars is disagreement between the state and its citizens over expedient and moral issues concerning human life and dignity. ${ }^{11}$ The difficulties being faced by the United States and other coalition forces involved in fighting the Global War on Terror (GWOT) in Iraq, Afghanistan, and other hot spots around the world seem to indicate the extent of the challenge that fighting asymmetric wars poses to regular armed forces, even when every norm related to democratic principles and justice is overlooked and often deliberately violated in the quest to win the war at all costs. One has to keep in mind, however, that the above examples are cases of democratic states intervening externally in foreign countries, instead of combating domestic insurgencies. When one considers the

10 See Harold A. Gould and Franklin C. Spinney, "Fourth Generation Warfare," The Hindu (9 October 2001).

11 Gil Merom, How Democracies Lose Small Wars (Cambridge: Cambridge University Press, 2003), 19. 
South Asian situation (while keeping in mind the increasing role of the United States in counter-insurgency operations in Pakistan), one may argue that most counter-insurgency operations are to a large extent domestically organized by forces of the concerned states:

New factors - such as the explosion in the number of actors present in today's irregular warfare battle space, including various multilateral organizations, volunteer forces, diasporic groups, and private military/security companies - have rendered the previous generation of counter-insurgency tactics virtually obsolete. ${ }^{12}$ This is demonstrated by the necessity for the global armies that are primarily involved in such operations to come up with new exclusive manuals or guides dealing with counter-insurgency operations. The U.S. Army, for instance - which until very recently was nearly obsessed with the prospects of high-tech future wars - had to issue its first new field manual on counter-insurgency in more than twenty years as it found itself becoming involved in several major counter-insurgency campaigns. ${ }^{13}$ The major feature of such counter-insurgency operations is, as described in the U.S. Field Manual, a mix of offensive, defensive, and stability operations conducted along multiple lines of operations. Such campaigns require soldiers to employ a mix of familiar combat tasks and skills more often associated with non-military agencies. ${ }^{14}$ The ultimate objective of such arrangements is for military forces, police, and other security forces to establish effective control while attaining a monopoly on the legitimate use of violence within the society experiencing conflict. Doubts, however, have already been raised about the effectiveness of the new counter-insurgency doctrine against an increasingly diffused enemy that is almost impossible to clearly identify. As Frank Hoffman has noted, [one] implication of how diverse insurgent battlespace is becoming is the difficulty of simply defining the nature of the opponent, and assessing his strategy, structure, and means. ... Future threats may pose a range of potential organizational structures, including traditional and fixed hierarchical structures led by charismatic individuals. They may organize into loosely affiliated networks, linked by a key individual, common ideology, or common enemies. They may elect to follow a more cellular structure, exercising greater autonomy and less connectivity than the old formal networks. Lastly, such organizations may employ hybrid structures, where specific capabilities or financial support are provided to local cells in an attempt to augment their functional capability for a single mission. ${ }^{15}$

More specifically, for instance, the Indian Army's counter-insurgency strategy has acknowledged the impossibility of achieving any final military victory in an asymmet-

12 Frank G. Hoffman, “Neo-Classical Counterinsurgency,” Parameters 37:2 (Summer 2007): 74.

13 James S. Corum, "Rethinking U.S. Army Counter-insurgency Doctrine," Contemporary Security Policy 28:1 (April 2007): 127-28.

14 Counterinsurgency, Field Manual 2-24 (Washington, D.C.: Department of the Army, December 2006).

15 Hoffman, "Neo-Classical Counterinsurgency," 75. 
ric war. The strategy instead emphasizes the political resolution of insurgencies, and places severe limitations on the use of military force in counter-insurgency operations. ${ }^{16}$

Another area of concern in an era of diffuse security concerns and threats is the movement toward increasing privatization and commodification of security. The process of globalization is splintering the concept of national security, generating new markets for both supra-national and sub-national security providers. In international relations, a noticeable trend in this connection has been the rise of private military companies (PMCs) and private security companies (PSCs) and their use by agencies of the state as well as by "international organizations, NGOs, humanitarian agencies, members of the international media, and MNCs [multi-national corporations]...." ${ }^{17}$ In the domestic sphere, internal security is also becoming increasingly privatized, as private security companies and other non-state agents supplant state agencies as providers of individual security. ${ }^{18}$

This has either been because of the failure of weak states or, in cases of stronger states, as a part of the overall drive toward outsourcing in pursuit of greater efficiency and cost-effectiveness. The trend toward the privatization of security is already particularly evident in connection with process concerning the withdrawal and/or failure of the state. Internally, with rising concerns about the breakdown of law and order or civilian security, groups and institutions that can afford it are increasingly turning to private security agencies rather than depending upon the state. The rising prominence of the PSCs has been one part of this paradigm. Another area of the privatization of security has been the increasing role played by non-state actors and groups oriented toward addressing the sources of conflict, whether those groups operate internally, regionally, or globally. The increasing threat potential of various terrorist and insurgent groups like the Maoists is an indicator of this trend. The privatization of security and the increasing employment of PSCs as well as amorphous vigilante groups have been advocated, in certain quarters, as a better approach to dealing with such new threat scenarios and conflicts. When put into practice, however, this approach has raised several concerns. Most nations' existing laws and regulations regarding the use of private security organizations are insufficient to prevent any misuse, when they are present at all. Accusations of mismanagement, theft, and corruption have been raised regarding the use of PSCs. More importantly, one must consider whether security privatization poses a danger of further eroding state authority at a time when the structure of the nation-state is already facing severe assault from within and without. Another problem is that privatization can lead to the commodification of both conflict and security, which

16 Rajesh Rajagopalan, "'Restoring Normalcy”: The Evolution of the Indian Army's Counterinsurgency Doctrine," Small Wars \& Insurgencies 11:1 (2000): 44.

17 Caroline Holmqvist, Private Security Companies: The Case for Regulation, SIPRI Policy Paper 9 (Stockholm: SIPRI, 2005), 6.

18 Bjorn Moller, "Privatisation of Conflict, Security and War," DIIS Working Paper 2005/2, (Copenhagen: Danish Institute For International Studies, 2005), 8. 
can in turn make these phenomena self-perpetuating as they are increasingly determined by the application of financial considerations.

Following the "securitization model" laid out by Ole Waever and Barry Buzan, some scholars have also criticized the tendency on the part of the state to overtly securitize insurgent movements, a reaction that tends to create more problems. The next section will offer an analysis of some of the above-mentioned theoretical concerns as they have played out in the Indian context.

\section{Fighting Insurgency: The Indian Context}

Insurgency against the state has been a familiar problem in South Asia, one that continues to confront nearly all states in the region. Many states in Asia are weak and new entrants to the international order, having served as "peripheries" to the Western colonial powers. Moreover, being recent entrants to the global world order following their emergence from the undifferentiated classification of the Third World, most of these countries wished to pursue their own agendas of development. In many cases, these development programs often intensified the already existing societal differences over issues related to the distribution of the proceeds of the development process, leading to conflict situations. Most of the South Asian countries also neither possess the resources nor the capabilities to exert monopoly control over the use of violence. Many of the states in the region are also subject to societal conflicts originating from long-standing identitarian loyalties (particularly ethno-religious sentiments) shared by demographically significant groups or communities, which often turn into major challenges to the states in the form of insurgent-dominated secessionist movements or other movements that threaten to alter existing state structures.

It is generally accepted, however, that within the region, India has been able to tackle the insurgency question in a far more satisfactory manner than its regional neighbors. Insurgency has been a festering problem since the emergence of India as a separate nation-state in 1947. Apart from ethno-religion-based separatist movements like those that were active in the Punjab during the 1980s, or in the state of Jammu and Kashmir, India also continues to experience insurgencies based on radical political/ ideological movements like the one led by the Naxalites. The general principle of the Indian state has been to use force against the groups that advocate or practice violence in pursuit of their objectives. The impact of the post-Cold War developments outlined above has been felt in the South Asian region as well, making the task of dealing with insurgencies more difficult. Such new trends have been considered important enough for the Indian Army, for instance, to come out with its own Manual on Subconventional Warfare in 2006. This manual defines "sub-conventional warfare" as a generic term encompassing all armed conflicts that are above the level of peaceful coexistence among states and below the threshold of war. It includes militancy, insurgency, proxy war, and terrorism, whether employed as a means in an insurrectionist movement or undertaken independently. Border skirmishes also fall within this cate- 
gory. ${ }^{19}$ The manual defines counter-insurgency operation as involving "the use of all measures of government activity to combat insurgency, including operations by the military, central paramilitary forces, economic development, political reforms and perception management aimed at winning the 'hearts and minds' of the people. ${ }^{20}$

The main aim of such operations is conflict resolution through the process of effecting changes in public opinion among the groups that give rise to insurgent movements. Naturally, such efforts cannot be achieved through military operations alone, but involve a greater level of inter-agency coordination and a lesser emphasis on violence. As the manual states, "The end state sought by a national counter-insurgency campaign is always 'conflict resolution,' which generally succeeds 'conflict termination.' This entails demilitarization of the conflict zone and shaping the environment, wherein the remaining differences can be pursued without violence. The requisite shaping of the environment is affected through a concurrent application of all elements of national power. This involves addressing the root causes of the problem in right

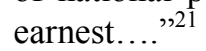

Thus, it has been argued that the Indian Army's counter-insurgency operations

employed both political measures and military force. Though each iteration of these combinations of efforts looks messy and sui generis, there is a common underlying grand strategy. On the other hand, it is difficult to say whether this is a conscious strategy or whether it has evolved out of the deep background of Indian strategic culture. The essence of this strategy is the willingness to compromise with rebellious sub-nationalities on all issues with one exception: secession is taboo. In order to permit such compromises, it was essential that military force be kept carefully limited - though force was used, and frequently. This grand strategy was evident in all the major counter-insurgency campaigns, and it has been effective in avoiding defeat, a major objective in guerrilla wars. ${ }^{22}$

Rajesh Rajagopalan has written about the five basic elements of the Indian Army's counterinsurgency doctrine - elements that, according to him, explain the relatively high success rate of the Indian Army in containing insurgency. These are:

- The limitation on the use of military force

- Isolation of insurgents from the general population

- Achieving domination over the affected area

- Maintenance of large forces in combat zones

19 Doctrine for Sub-Conventional Operations (New Delhi: Integrated Headquarters of Ministry of Defense (Army), December 2006), 1.

20 Ibid., Appendix A, 65.

21 Ibid., 17.

22 Rajesh Rajagopalan, "Force and Compromise: India's Counter-Insurgency Grand Strategy," South Asia: Journal of South Asian Studies 30:1 (2007): 84. 
- A firm belief that there is no permanent military solution to counterinsurgency problems, which ultimately have to be resolved politically. ${ }^{23}$

In contrast, one could point to the dismal counter-insurgency operations currently being conducted by the Pakistani Army in the conflict-torn areas of Pakistan. According to one assessment,

with a dismal track record in counter-insurgency and a traditional outlook focused solely on fighting a conventional war against India, the Pakistani Army seems to have adopted an ad hoc strategy. The self-proclaimed invincibility of the armed forces initially prompted it to use a firepower-intensive approach, demonstrated by the frequent use of weapons like helicopter gunships and artillery. The use of brute force instead of low-intensity strikes is a classic flaw in counter-insurgency campaigns: its military effectiveness is suspect, and it invariably embitters the local population. But when these heavy-handed operations fail — as they are bound tothe army has been clueless about alternatives and pulls back completely in favor of political and economic 'peace agreements' with insurgents. ${ }^{24}$

The overt use of heavy force (with enormous amounts of war materiel being pumped in by China and Pakistan) has also been a major tactic employed by the Sri Lankan Army in finally crushing the Liberation Tigers of Tamil Eelam (LTTE), though time will only tell whether this overwhelming military victory will lead to more profound conflict resolution in the island nation. The Royal Nepalese Army's long struggle with the Maoist insurgent movement there, on the other hand, has ended in a military stalemate.

Ultimately, if the $4 \mathrm{GW}$ model does in fact describe this new mode of insurgencydriven conflict, then such conflicts are primarily battles of political will and determination, rather than of arms. Indeed, there cannot be any final military solution. Moreover, no matter how "low-key" their level of engagement, the continuous involvement of state security forces - particularly the army and paramilitary forces - in such internal conflict zones can project the image of the state security forces as an "occupying force," a tag that any national army would like to avoid. Several members of the Indian Army leadership have repeatedly warned against the dangerous implications involved in the continuous presence of the army in internal conflict situations. The tendency on the part of the ruling elites in South Asia has, however, been to approach insurgency primarily as a law and order problem. Attempts to seek a solution only through the application of force often lead to an overt securitization of the problem.

23 Rajesh Rajagopalan, "Fighting Fourth Generation Wars: the Indian Experience," in Global Insurgency and the Future of Armed Conflict: Debating Fourth-Generation Warfare, eds. Terry Terriff, Aaron Karp, and Regina Karp (London: Routledge, 2007), 263-66.

24 Moeed Yusuf and Anit Mukherjee, "Counterinsurgency in Pakistan: Learning from India," National Security Outlook, American Enterprise Institute for Public Policy Research (September 2007); available at www.aei.org/publications/pubID.26888,filter.all/pub_detail.asp. 


\section{State Tendencies to Securitize Insurgencies}

According to the scholars affiliated with the Copenhagen School (most notably Ole Waever and Barry Buzan, mentioned above), military, political, economic, social, and environmental sectors are the various fields in which securitization can potentially take place. If a subject is successfully securitized, it is possible to legitimize the employment of extraordinary means to solve a perceived problem. This could include declaring a state of emergency or martial law, mobilizing the military, or attacking another country. Furthermore, if an issue is successfully labeled as a security problem, the subject can be considered to be an illegitimate subject for political or academic debate. Once securitization has taken place, the license to bend or break democratic rules does not require the grant of legitimacy from the public in the form of a referendum, but can be exercised unilaterally by the state. The Indian state, as Shamuel Tharu argues, has over time incorporated into the legal system a whole array of legislation and ordinances that prolong its right to exercise exceptional powers indefinitely. ${ }^{25}$

Overt securitization of social or political problems has often led to the neglect of the governance issues involved, as establishing the state monopoly on the use of violence (often through the adoption of extraordinary measures) becomes the main counter-insurgency strategy of the Indian state. This has unfortunately led to the fracturing and proliferation of conflicts rather than to their resolution.

For instance, in the Northeast, which is one of the most insurgency-prone regions in India, in spite of a perceptible decline in insurgency-related activities directed against the state apparatus, there has ironically been a sharp increase in the number of small violent organizations. As one analyst writes:

The multiplication of violent organizations is explained by the increasing percentage of attacks in the region aimed at inter-communal struggles, local provision of protection, political extortion, and crime. None of these activities is directly related to a major gap in the coercive penetration of the area by the military or a well-articulated, popular set of grievances. Instead, such violence is enabled by the abysmal condition of rule of law that endures in the Northeast even as mass insurgency has been curtailed. ${ }^{26}$

As it has been implemented to this point, the Indian government's development strategy for the Northeast has failed to produce the desired results. The state- and sector-level plans of the Planning Commission have not been able to provide enough impetus for local development, or to generate processes of self-sustained growth. Instead of creating an efficiency-oriented economic process, this policy framework has resulted in the creation of a politicized distribution-oriented process. The result is that natural resources, profits, savings, and the like are, in fact, moving away from the Northeast to

25 Shamuel Tharu, "Insurgency and the State in India: The Naxalite and Khalistan Movements," South Asian Survey 14:1 (2007): 98.

26 Bethany Lacina, "Does Counterinsurgency Theory Apply in Northeast India?" India Review 6:3 (July-September 2007): 174 
other high productivity regions. In addition, the region's almost total dependence on funds and planned direction from the Indian capital has promoted a trait of passiveness toward development and has encouraged patronage and corruption. It has also created a government monopoly on employment, which has destroyed the work ethic necessary to build a modern economy. ${ }^{27}$ According to a Northeast-based commentator, for instance:

One senses a definite change of attitude in the people of the region. They have realized the futility of violence and bloodshed and want to move on with their lives. People are ready to partner with governments in progress. They want a stake-holdership in development. The moot point is whether governments in the Northeast are ready for this radical shift. Obviously politicians have to shift gears. For too long they have blamed militancy for lack of development. This is no longer acceptable ... One thing is for sure: money fuels insurgency and not the lack of it. ${ }^{28}$

Thus, the Indian counter-insurgency strategy in the region requires the government (and the military) to take into account the myriad factors at work in the Northeast and weave these into a comprehensive policy framework. Instead, as Vijendra Singh Jafa notes,

The handling of the development of various secessionist insurgencies in the northeast, the manner in which they have been sought to be resolved, and the efforts by the government and its agencies to negotiate settlements has been a squalid, slovenly and dismal affair. In the process, a few retired civil servants and police affairs have promoted themselves into a class of professional negotiators or peace-brokers who criss-cross the planet to negotiate with surrealistic insurgent leaders in surrealistic environments at great public expenses and without achieving any breakthrough. ${ }^{29}$

Another aspect of the Indian state's counter-insurgency strategy has been to organize various vigilante groups and pro-government militias, often consisting of surrendered or renegade members of the insurgent groups. Use of such pro-government private groups has been a complementary effort to the more traditional application of force through the army and paramilitary groups and the police. In Assam, for instance, where the Indian state has been facing a long-term threat from the United Liberation Front of Assam (ULFA), a pro-India outfit labeled the SULFA (Surrendered ULFA) was created in 1992, made up of surrendered militants, as the name suggests. These

27 Gulshan Sachdeva, "India's North East: Rejuvenating a Conflict-Riven Economy," Manipur Online (6 February 2006); available at www.manipuronline.com/Economy/February2006/ conflictriveneconomy06_1.htm.

28 Patricia Mukhim, "Time to Move On," The Statesman (online edition) (24 August 2009); available at http://www.thestatesman.net/index.php?option=com_content\&view=article\&id= 304014:Redefining the insurgencies\&catid=52:north-east-page\&from_page=search.

29

Vijendra Singh Jafa, "Insurgencies in North-East India: Dimensions of Discord and Containment," in Responding to Terrorism in South Asia, ed. S.D. Muni (New Delhi: RCSS \& Manohar, 2006). 
former ULFA members were allowed to retain their weapons to defend themselves against possible ULFA retaliation, and were also offered special government benefits. However, reports indicate that many members of the SULFA have also become involved in criminal and other illegal activities, including extortion. The SULFA has also been used by the state to target the family members and sympathizers of the ULFA in order to pressure them to come to terms with the government. According to Ajai Sahni and Bibhu Prasad Routray,

The foundations of SULFA's growth lie ... first, in the enormous quantum of financial resources that it has come to control, and that it recycles through the political leadership and the bureaucracy in the state; and second, possibly more significantly, in the degree to which violence now pervades the politics of the state. The result is that all political parties seek alliances of convenience with the SULFA - as they do, from time to time, with the ULFA. To the extent that the ULFA operates in the context of an ideology that makes anti-state violence essential for credibility, its relationship with successive regimes is inherently volatile and unsound. The SULFA, on the other hand, offers the possibilities of relatively stable collusive arrangements. Stability, it has been remarked, is integral to the character and continued existence of collusive arrangements. ${ }^{30}$

In another major conflict zone within India, the state of Jammu and Kashmir, several counter-militant groups have been operating since the 1990s, the most important of which is the Ikhwan-i Muslimi. According to one Human Rights Watch report, although the Indian government routinely denies any responsibility for the actions of these groups, they are organized and armed by the Indian Army and other security forces and operate under their command and protection, primarily targeting the proazadi or pro-Pakistan militant groups and their political sponsors and sympathizers. ${ }^{31}$

Several cases of human rights violations and illegal activities have been also alleged against several members of the Ikhwan. Since 2004, however, the Ikhwanis have been made part of the Home and Hearth Territorial Army.

Another recent example of such a state-sponsored private counter-insurgency group has been the Salwa Judum, encouraged and initiated by the Chhattisgarh government as a popular movement against the Naxalite-led wave of terrorism in June 2005. However, recent reports indicate that, contrary to its claims, instead of being a spontaneous movement of tribal leaders against Maoist radicals, the Salwa Judum is in fact an organized, state-managed enterprise that has precedents in the previously formed $\mathrm{Jan} \mathrm{Ja-}$ garan Abhiyans. ${ }^{32}$ Moreover, recent media reports indicate a rising number of human

30 Ajai Sahni and Bibhu Prasad Routray, "SULFA: Terror by Another Name," Faultlines 9 (2001); available at www.satp.org/satporgtp/publication/faultlines/volume9/Article1.htm.

31 Human Rights Watch, "Behind the Kashmir Conflict: Abuses by the Indian Security Forces and Militant Groups Continue," 1999; available at http://www.hrw.org/reports/1999/kashmir/ militias.htm.

32 Press release, "Fact-finding report on the Salwa Judum, Dantewara District," Raipur (2 December 2005); available at http:/www.pucl.org/Topics/Human-rights/2005/salwa-judumreport.htm. 
rights violations on the part of the Salwa Judum. In fact, the rivalry between the Salwa Judum and the Naxalite groups has blossomed into a veritable civil war, leading to the collapse of civilian administration in several parts of the state, jeopardizing the security of the citizens rather than enhancing it.

\section{Conclusion}

When undertaking efforts to mitigate the threat of evolving insurgency, democracies like India will be tempted to adopt illiberal policies at home and abroad. Doing so, however, is not going to serve their national interests. Many states within the region of South Asia fit into the model of "low-intensity democracies" - that is, nations trying to seek a balance between frictions resulting from increasing rates of social mobilization and opposing forces from conservative elements at the top. ${ }^{33}$ In such countries, the army often plays a determining role in shaping the nature of policy to be pursued with respect to insurgent movements, one that is generally conservative. Civil liberties, however, are invaluable, not just because of their moral benefits to society, but also because of their practical advantages in counter-terrorism efforts. The inclination to adopt illiberal countermeasures must therefore be weighed against the realization that such tactics, while sometimes expedient in the short term, may ultimately jeopardize the outcome of counter-terrorism campaigns, creating new incentives for rational terrorist actors to attack. ${ }^{34}$ As Samir Kumar Das has noted with respect to Indian policy in the Northeast, "It is now being increasingly realized that the transition from a colonial society to a post-colonial one has a critical bearing on the character and conduct of counter-insurgency operations (CIO). The colonial modes of CIO are both irrelevant to and counter-productive in a post-colonial society., 35

In connection with the ongoing counter-insurgency operations in Afghanistan, Ali Jalali stated in testimony before the U.S. House of Representatives that:

The rule of law is the heart of government legitimacy and a prerequisite for human security that involves protection and empowerment of the citizenry. The dominance of security demands in an unstable environment has led to an over-securitization of the rule of law. This subordinates justice to security. ... Obviously in conflict-ridden conditions there is a need to deal with security threats in a forceful way; how-

33 Barry Gills and Joel Rocamora, "Low Intensity Democracy," Third World Quarterly 13:3 (1992): 501-23.

34 Max Abrahms, "Why Democracies Make Superior Counterterrorists," Security Studies 16:2 (April-June 2007): 250-51.

35 Samir Kumar Das, "Ethnic Conflicts and Internal Security: A Plea for Reconstructing Civil Society in Assam," Faultlines 10 (2002); available at www.satp.org/satporgtp/publication/ faultlines/volume10/Article3.htm. 
ever, the approach should not result in compromising the administration of justice since the rule of law contributes to security in a major way. ${ }^{36}$

The best counter-insurgency model that could be adopted by the South Asian countries in this regard is that of Security Sector Reform (SSR). As Francesco Mancini has argued, the recent emergence of SSR has provided a way to tackle security and development questions simultaneously: "It combines a wide range of activities that reform the security institutions of the state - the military, police, intelligence services and the criminal justice system - in order to make them capable of delivering security to citizens in a way that is consistent with democratic norms. It is an increasingly common element of development policy." ${ }^{37}$

Thus, the states in South Asia - and particularly India — have to extend their counter-insurgency strategies beyond military operations. What is alarming is that they are largely perceived as having failed to do so. Overt securitization of the problem of insurgency without adequate restoration of governance in the affected regions is going to be largely ineffective in solving the problem of modern insurgency, whether or not it has evolved into fourth-generation warfare.

${ }^{36}$ Ali Jalali, Testimony Before the Committee on Armed Services, U.S. House of Representatives, 30 January 2007; available at http://www.ndu.edu/nesa/docs/webfile/ jalalitestimony30jan07.pdf

37 Francesco Mancini, In Good Company? The Role of Business in Security Sector Reform (London: Demos, 2005), 13. 


\section{Bibliography}

Abrahms, Max. "Why Democracies Make Superior Counterterrorists." Security Studies 16, no. 2 (2007): 250-51.

Behind the Kashmir Conflict: Abuses by the Indian Security Forces and Militant Groups Continue. Human Rights Watch, 1999.

Corum, James S.. "Rethinking U.S. Army Counter-insurgency Doctrine." Contemporary Security Policy 28, no. 1 (2007): 127-28.

Das, Samir Kumar. Ethnic Conflicts and Internal Security: A Plea for Reconstructing Civil Society in Assam. Faultlines, 2010.

Doctrine for Sub-Conventional Operations. New Delhi: Integrated Headquarters of Ministry of Defense (Army), 2006.

Evans, Michael. "Elegant Irrelevance Revisited: A Critique of Fourth-Generation Warfare." Contemporary Security Policy 26, no. 2 (2005): 245.

Fact-finding report on the Salwa Judum, Dantewara District In Press release. Raipur, 2005.

Gills, Barry, and Joel Rocamora. "Low Intensity Democracy." Third World Quarterly 13, no. 3 (1992): 501-23.

Gould, Harold A., and Franklin C. Spinney. "Fourth Generation Warfare." The Hindu (2001).

Hammes, Thomas X.. The Sling and the Stone: On War in the 21st Century. New Delhi: Zenith Press \& Manas Publishers, 2006.

Hoffman, Frank G.. "Neo-Classical Counterinsurgency." Parameters 37, no. 2 (2007): 74.

Holmqvist, Caroline. Private Security Companies: The Case for Regulation In SIPRI Policy Paper. Stockholm: SIPRI, 2005.

Jackson, Paul. "Is Africa Seeing Fourth Generation Warfare, Or is the Model Flawed?" Small Wars and Insurgencies 18, no. 2 (2007): 147.

Jafa, Vijendra Singh. "Insurgencies in North-East India: Dimensions of Discord and Containment." In Responding to Terrorism in South Asia. New Delhi: RCSS \& Manohar, 2006.

Jalali, Ali. Testimony Before the Committee on Armed Services. U.S. House of Representatives, 2007.

Keegan, John. A History of Warfare. London: Pimlico, 1994.

Lacina, Bethany. "Does Counterinsurgency Theory Apply in Northeast India?" India Review 6, no. 3 (2007): 174. 
Lind, William S., Keith Nightengale, John F. Schmitt, Joseph W. Sutton, and Gary I. Wilson. "The Changing Face of War: Into the Fourth Generation." Marine Corps Gazette (1989): 22-26.

Mancini, Francesco. In Good Company? The Role of Business in Security Sector Reform. London: Demos, 2005.

Mearsheimer, John J.. "Why We Will Soon Miss the Cold War." The Atlantic Monthly (1990): 35 .

Merom, Gil. How Democracies Lose Small Wars. Cambridge: Cambridge University Press, 2003.

Moller, Bjorn. Privatisation of Conflict, Security and War In DIIS Working Paper. Copenhagen: Danish Institute For International Studies, 2005.

Murden, Simon. "Staying the Course in Fourth-Generation Warfare." In Dimensions of Counter-Insurgency: Applying Experience to Practice, 192. New York: Routledge, 2008.

Rajagopalan, Rajesh. "Fighting Fourth Generation Wars: the Indian Experience." In Global Insurgency and the Future of Armed Conflict: Debating Fourth-Generation Warfare, 263-66. London: Routledge, 2007.

Rajagopalan, Rajesh. "Force and Compromise: India's Counter-Insurgency Grand Strategy." South Asia: Journal of South Asian Studies 30, no. 1 (2007): 84.

Rajagopalan, Rajesh. "Restoring Normalcy': The Evolution of the Indian Army's Counterinsurgency Doctrine." Small Wars \& Insurgencies 11, no. 1 (2000): 44.

Rotberg, Robert I.. "Failed States, Collapsed States, Weak States: Causes and Indicators." In State Failures and State Weakness in a Time of Terror, 3. Washington, D.C.: The World Peace Foundation \& Brookings Institution Press, 2003.

Sachdeva, Gulshan. India's North East: Rejuvenating a Conflict-Riven Economy. Manipur Online, 2006.

Sahni, Ajai, and Bibhu Prasad Routray. SULFA: Terror by Another Name. Faultlines 9, 2001.

Tharu, Shamuel. "Insurgency and the State in India: The Naxalite and Khalistan Movements." South Asian Survey 14, no. 1 (2007): 98.

Yusuf, Moeed, and Anit Mukherjee. Counterinsurgency in Pakistan: Learning from India In National Security Outlook. American Enterprise Institute for Public Policy Research, 2007. 